\section{Dr. Díaz Donado replies}

\section{To the Editor:}

I congratulate Caramaschi and colleagues for achieving the best outcome for their patients ${ }^{1}$.

In trials, in new procedures in medicine, it is very important to use accurate terms, in an appropriate way. "Desensitization procedure" 2 means an attempt to induce tolerance to an offending drug. To name the process desensitization we must have demonstrated that the drug caused the reaction by an allergic mechanism (Gell-Coombs classification ${ }^{3}$ ).

Anaphylaxis related to hydroxychloroquine ${ }^{4}$ was the first reported case of a desensitization procedure with a demonstrated IgE-mediated mechanism with this kind of drugs. The desensitization procedure was carried out successfully.

None of the studies of Mates, et $a l^{5}$ and Caramaschi, et al have shown any evidence of an immunological mechanism responsible for the reaction. The patients have tolerated the drug; from a clinical point of view this procedure has been shown to be very useful, but none of the described procedures can be termed desensitization procedures. We do not know which circumstances could explain the tolerance to the offending drug, an effective desensitization procedure or perhaps another explanation. It is typical for simple drug-induced exanthems to resolve spontaneously even if the offending drug is not discontinued. A great number of patients who have suffered a drug-induced exanthema do not undergo a positive oral rechallenge. There could be another explanation. The author has not proved that the readministration of the drug caused any reactions. Sometimes to avoid the onset of adverse events, especially cutaneous events, it is enough to readminister the drug beginning with small doses, increasing slowly through weeks or days to achieve the total desired dose $\mathrm{e}^{6,7}$.

According to Sontheimer ${ }^{8}$, "It would seem premature [for the authors] to speculate about tolerance-inducing capabilities of this desensitization regimen based on the data presented". The authors have not proved an immunological mechanism responsible for the cutaneous reaction.

I insist on consulting staff of allergy units who are specialists in the handling, study, and treatment of drug-related reactions. The reactions should be studied in order to establish in which patients it is sufficient to readminister the drug in question with caution, and in which patients it is necessary to carry out a desensitization procedure.

CARMEN DÍAZ DONADO, PhD, Alergología, Hospital Universitario Central Asturias, Doctor Bellmunt s/n, Oviedo, 33006

Spain.E-mail: cdiazd@seaic.es

\section{REFERENCES}

1. Caramaschi P, Barbazza R, Itinazzi I, Biasi D. Desensitization to hydroxychloroquine: 4 cases [letter]. J Rheumatology 2011;38:2267.

2. Audicana Berasategui MT, Ortega Rodriguez NR, Garcia Ortega P, Uriel Villate O. Prevención y tratamiento de las reacciones a los fármacos. In: Pelaez Hernandez A, Davila Gonzalez I, editors. Tratado de alergología. Tomo II: Chapter 69: 1369-95. Madrid: Ergon Edition; 2007.

3. Vervloet D, Durham S. Adverse reaction to drugs. BMJ 1998;316:1511-4.

4. Díaz Donado C, Maquiera Díez E. Successful desensitization for hydroxychloroquine anaphylaxis [letter]. J Rheumatol 2010;37:1975-7.

5. Mates M, Zevin S, Breuer GS, Navon P, Nesher G. Desensitization to hydroxychloroquine - experience of 4 patients. J Rheumatol 2006;33:814-6.

6. Reveuz J, Valerie-Allanore L. Drug reaction. In: Bolognia JL, Jorrizo JL, Rapini RP, editors. Dermatology. 1st ed. London: Mosby; 2003:333-53.

7. Yawalkar N. Drugs-induced exanthems. Toxicology 2005; 209:131-4

8. Sontheimer RD. Desensitization to hydroxychloroquine: alternative interpretations [editorial]. J Rheumatol 2007;34:253-5.

J Rheumatol 2011;38:10; doi:10.3899/jrheum.110515 